\title{
Contents of Volume 10
}

Beekman, M.M. and Struijs, P., The quality of economic concepts and definitions 1

Beer, J. de, Kuijper, H., Noordam, R., Prins, K. and Sprangers, A., The linking of immigrant flow and stock data in the Netherlands; present and future possibilities

Belov, N.G., On main directions of CIS Statistical Committee activities in organizing statistics according to market economy conditions

Blanke, K., Objectives and background of the German time use study 1991/1992 65

Boo, A.J. de, Costs of integrated environmental control 47

Boucneau, M., see Darius, P.

CES

- The Statistical metadata project under the Conference of the European Statisticians (A note by the secretariat)

Cimermanović, B., see Dumičić, S.

Darius, P., Boucneau, M., de Greef, P., de Feber, E. and Froeschl, K., Modelling metadata

Deecker, G., Murray, T.S. and Ellison, J., On providing client support for machine readable data files

Dumičić, K., see Dumičić, S.

Dumičić, S., Cimermanović, B. and Dumičić, K., Developing the Business Register in Croatia

Ellison, J., see Deecker, G.

Feber, E. de, see Darius, P.

Franchet, Y., Metadata and official statistics

Franz, A., Some thoughts on systems of regional accounts

Froeschl, K., see Darius, P.

Froeschl, K.A., Towards an operative view of semantic metadata

Gouiedo, L.H., Proposals for a set of cultural indicators 
$\begin{array}{ll}\text { Greef, P. de, see Darius, P. } & 171\end{array}$

Hand, D.J., Data, metadata and information 143

Keyfitz, N., Increasing the accuracy and usefulness of the GDP 371

Kuijper. H., see Beer, J. de 321

Latten, J.J. and Veenstra, C.J., A changing society and its population statistics: reorientations in the Netherlands

Lenz, H.-J. and Neumann, K., Introduction - international workshop on statistical metainformation systems

Lisagor, L., see Malmborg, E. 195

Malmborg, E. and Lisagor, L., Implementing a statistical metainformation system 195

Miscellany

- The stop-watch game of tennis (B. Wicklin) 77

- Planned work by the Conference of European Statisticians in the field of social and demographic statistics, 1993-1996

- Coordination of technical assistance in statistics to the countries of the former Soviet Union (Statistics Department of the IMF)

Müller, W., Health expenditure, 1970 to 1989

Murray, T.S., see Deecker, G. 209

Neumann, K., see Lenz, H.-J.

$\begin{array}{ll}\text { Noordam, R., see Beer, J. de } & 321\end{array}$

$\begin{array}{ll}\text { Nordbotten, S., Statistical meta-knowledge and -data } & 101\end{array}$

Podehl, M., User requirements for statistical metainformation 113

$\begin{array}{ll}\text { Prịns, K., see Beer, J. de } & 321\end{array}$

Saijets, M., The unified file system and its metadata part 201

Silver, M., The role of footnotes in a statistical metainformation system 153

Sprangers, A., see Beer, J. de 321

Struijs, P., see Beekman, M.M.

Sundgren, B., Statistical metainformation systems - pragmatics, semantics, syntactics

Veenstra, C.J., see Latten, J.J. 